\title{
12. PRELIMINARY PALEOMAGNETIC RESULTS FOR SEDIMENTS FROM SITE 263, LEG 27
}

\author{
Kenneth E. Green and Aviva Brecher, Massachusetts Institute of Technology \\ Earth and Planetary Sciences Department, Cambridge, Massachusetts
}

\begin{abstract}
Paleomagnetic measurements on four cores recovered at Site 263 of sediments thought ot be of Albian to early Barremian age (100115 m.y.) reveal three periods of reversed geomagnetic field. Statistically significant clustering sample remanent inclination values suggests that the average paleolatitude calculated for the site is highly reliable. There is close agreement between the site's paleolatitude according to these data $\left(44.3^{\circ} \pm 5.5^{\circ}\right)$ and that computed from the Cretaceous pole for continental Australia of about $48.4^{\circ}$.
\end{abstract}

\section{EXPERIMENTAL METHODS}

We have carried out paleomagnetic studies on 41 samples from 13 intervals in four sediment cores recovered at Site 263 , located at $23^{\circ} 20^{\prime} \mathrm{S}, 110^{\circ} 58^{\prime} \mathrm{E}$, in the Cuvier Abyssal Plain. The samples were cut and oriented by R. D. Jarrard at Scripps Institution of Oceanography, as described elsewhere in this volume. The 6-cc samples consist of very firm kaolinitic, quartz-bearing clay. Sample positions are given in Table 1 and are plotted in Figure 1. Because the sedimentation rate was initially thought to be $8 \mathrm{~cm} /$ thousand years (Core Log, this volume), up to five samples were taken from each interval to improve the statistical significance of the measurements. The natural remanent magnetization (NRM) of the samples was measured on a $5-\mathrm{Hz}$ Schonstedt (SSM-1A) spinner magnetometer with a sensitivity of better than $1 \times 10^{-7} \mathrm{emu}$.

The components along the vertical and the horizontal sample axes were measured by one of two means. In the first method, a six-spin procedure similar to that described by Doell and Cox (1965) was carried out, and a daily correction for machine drift and holder moment was applied. A second method was developed to handle samples with very low intensity of one of the horizontal components, typically on the order of $1 \times 10^{-7} \mathrm{emu} / \mathrm{cc}$, which is near the machine limit. In the second method, 12 spins facilitate subtraction of the effects due to nonsample sources: the differences between these spins give the same set of four replicate measurements as before. Because these samples were spun in the closest position to the detector, they show some variation due to nonideal shape (cubic) and inhomogeneity. Thus, some of the variation in replicate measurements about different spin axes is real and due to nondipole contributions. An arithmetic mean and standard deviation for each component were calculated. The mean was used to determine the sample inclination and declination. Those samples with a standard deviation about the total remanent moment greater than $20 \%$ are not considered reliable, since their remanence is not well described by a dipole; they are noted in Table 1 as having a large nondipole component (LNC).
In order to remove secondary magnetic components, all samples were partially demagnetized (cleaned) in alternating fields (AF). To determine the amount of AF cleaning necessary, 15 samples were cleaned to a peak field value of 100 oe in 25 -oe steps. The intensity and direction upon progressive AF cleaning, for four representative samples, are plotted in Figures $2 a$ and $2 b$. The results for these 15 samples indicate that most of the soft, secondary component of remanence was removed in 50 -oe AF peak fields. Thus, the 26 remaining samples were AF demagnetized in 50-oe fields. In all cases the polarity remained the same as that of NRM after 50-oe cleaning, with the intensity reduced typically by $10 \%$ to $43 \%$.

\section{RESULTS}

Table 1 lists the results of measurements on the 41 samples. Inclinations are given with respect to the present horizontal, assuming vertical drill holes (positive downward). Negative inclinations correspond to normal polarity for these southern hemisphere cores. Because the absolute orientation is not known, declinations are relative to a given core barrel. Shearing during drilling and recovery may produce considerable scatter in the declinations for samples from different intervals. For these reasons, declinations are of no use in calculating paleocoordinates. The residual moments (after stepwise AF demagnetization) are also listed in Table 1, expressed as a percentage of initial NRM.

The inclinations and intensities $(\mathrm{emu} / \mathrm{cc})$ of both NRM and the residual after 50-oe cleaning, taken from Table 1, are plotted versus depth for the 41 samples in Figure 1. Note that the AF cleaning reduces the scatter in sample inclinations within each of the 13 sampling intervals. The inclination to be expected at Site 263, due to a present axial geocentric dipole, is marked at $40.8^{\circ}$. Note also that there is no simple correlation between NRM intensity and depth and that both normal and reversed polarity samples have similar intensities. Figure 3 shows the distribution of NRM inclinations, separately for normal and reversed samples, on $5^{\circ}$ histograms, 
TABLE 1

Results of Measurements (41 samples)

\begin{tabular}{|c|c|c|c|c|}
\hline $\begin{array}{c}\text { Sample } \\
\text { (Interval in } \mathrm{cm} \text { ) }\end{array}$ & $\begin{array}{l}\text { Demagnet- } \\
\text { izing Field } \\
\text { (oe) }\end{array}$ & $\begin{array}{c}\text { Magnitude }^{\mathrm{c}} \\
\left(\times 10^{-7} \mathrm{emu} / \mathrm{cc}\right) \\
\text { Residue }(\%)\end{array}$ & $\begin{array}{c}\text { Declination } \\
\text { Mean }\left({ }^{\circ}\right)\end{array}$ & $\begin{array}{c}\text { Inclination } \\
\text { Mean }\left({ }^{\circ}\right)\end{array}$ \\
\hline $20-1,100-102$ & $\begin{array}{c}\mathrm{NRM}^{\mathrm{a}} \\
25 \\
50 \\
75^{\mathrm{a}} \\
100^{\mathrm{a}}\end{array}$ & $\begin{array}{c}(4.99) \\
86 \\
71 \\
63 \\
53\end{array}$ & $\begin{array}{l}192.5 \\
186.3 \\
186.1 \\
196.6 \\
181.2\end{array}$ & $\begin{array}{l}-66.3 \\
-64.2 \\
-65.1 \\
-69.4 \\
-61.8\end{array}$ \\
\hline $20-1,102-104$ & $\begin{array}{c}\text { NRM } \\
25 \\
50 \\
75^{\mathrm{a}} \\
100^{\mathrm{a}}\end{array}$ & $\begin{array}{c}(4.84) \\
100 \\
57 \\
54 \\
47\end{array}$ & $\begin{array}{l}192.1 \\
189.8 \\
177.9 \\
190.3 \\
194.3\end{array}$ & $\begin{array}{l}-56.9 \\
-61.2 \\
-67.9 \\
-64.6 \\
-65.5\end{array}$ \\
\hline $20-3,26-28$ & $\begin{array}{c}\text { NRM } \\
25 \\
50 \\
75 \\
100\end{array}$ & $\begin{array}{c}(9.01) \\
86 \\
78 \\
65 \\
56\end{array}$ & $\begin{array}{l}31.5 \\
28.1 \\
36.7 \\
36.8 \\
28.8\end{array}$ & $\begin{array}{l}58.9 \\
62.2 \\
64.8 \\
64.0 \\
63.6\end{array}$ \\
\hline $20-3,28-30$ & $\begin{array}{c}\text { NRM } \\
25 \\
50 \\
75 \\
100\end{array}$ & $\begin{array}{c}(9.75) \\
86 \\
73 \\
62 \\
53\end{array}$ & $\begin{array}{l}17.4 \\
27.2 \\
29.2 \\
30.2 \\
23.2\end{array}$ & $\begin{array}{l}64.7 \\
61.9 \\
65.9 \\
61.8 \\
62.5\end{array}$ \\
\hline $21-2,0-2$ & $\begin{array}{c}\text { NRM } \\
50\end{array}$ & $\begin{array}{c}(8.43) \\
90\end{array}$ & $\begin{array}{l}253.3 \\
257.2\end{array}$ & $\begin{array}{l}-65.7 \\
-68.6\end{array}$ \\
\hline $21-2,4-6$ & $\begin{array}{c}\text { NRM } \\
25 \\
50 \\
75 \\
100\end{array}$ & $\begin{array}{c}(6.95) \\
96 \\
84 \\
81 \\
68\end{array}$ & $\begin{array}{l}224.8 \\
233.8 \\
237.4 \\
254.2 \\
255.8\end{array}$ & $\begin{array}{l}-60.6 \\
-65.9 \\
-68.6 \\
-71.6 \\
-70.5\end{array}$ \\
\hline $21-4,6-8$ & $\begin{array}{c}\text { NRM } \\
25 \\
50 \\
75 \\
100\end{array}$ & $\begin{array}{c}(6.95) \\
100 \\
77 \\
71 \\
65\end{array}$ & $\begin{array}{l}263.9 \\
267.7 \\
257.7 \\
259.2 \\
263.0\end{array}$ & $\begin{array}{l}64.4 \\
63.4 \\
55.1 \\
56.4 \\
57.0\end{array}$ \\
\hline $21-4,8-10$ & $\begin{array}{c}\text { NRM } \\
25 \\
50 \\
75 \\
100\end{array}$ & $\begin{array}{c}(6.77) \\
86 \\
77 \\
67 \\
59\end{array}$ & $\begin{array}{l}264.0 \\
253.6 \\
257.4 \\
257.1 \\
250.7\end{array}$ & $\begin{array}{l}63.4 \\
62.2 \\
62.8 \\
59.0 \\
60.7\end{array}$ \\
\hline $21-4,12-14$ & $\begin{array}{c}\text { NRM } \\
25 \\
50 \\
75 \\
100\end{array}$ & $\begin{array}{c}(7.28) \\
88 \\
83 \\
71 \\
64\end{array}$ & $\begin{array}{l}255.7 \\
260.2 \\
258.1 \\
252.4 \\
250.4\end{array}$ & $\begin{array}{l}61.9 \\
62.4 \\
64.5 \\
65.3 \\
63.4\end{array}$ \\
\hline $21-4,14-16$ & $\begin{array}{c}\text { NRM } \\
25 \\
50 \\
75 \\
100\end{array}$ & $\begin{array}{c}(8.36) \\
88 \\
79 \\
72 \\
64\end{array}$ & $\begin{array}{l}274.0 \\
271.0 \\
273.7 \\
274.3 \\
272.8\end{array}$ & $\begin{array}{l}63.0 \\
63.5 \\
64.2 \\
65.1 \\
65.3\end{array}$ \\
\hline $21-5,139-141$ & $\begin{array}{c}\text { NRM } \\
25 \\
50 \\
75 \\
100\end{array}$ & $\begin{array}{c}(2.69) \\
98 \\
84 \\
74 \\
66\end{array}$ & $\begin{array}{l}185.0 \\
191.7 \\
193.4 \\
200.5 \\
200.7\end{array}$ & $\begin{array}{l}-54.1 \\
-59.3 \\
-60.2 \\
-63.8 \\
-67.9\end{array}$ \\
\hline $22-1,0-2$ & $\begin{array}{c}\text { NRM } \\
25 \\
50 \\
75 \\
100\end{array}$ & $\begin{array}{c}(4.79) \\
95 \\
80 \\
69 \\
63\end{array}$ & $\begin{array}{l}144.0 \\
147.2 \\
147.7 \\
149.7 \\
144.1\end{array}$ & $\begin{array}{l}-48.3 \\
-50.7 \\
-55.1 \\
-56.5 \\
-55.5\end{array}$ \\
\hline $22-1,2-4$ & $\begin{array}{c}\text { NRM } \\
25 \\
50 \\
75 \\
100\end{array}$ & $\begin{array}{c}(4.21) \\
98 \\
83 \\
77 \\
66\end{array}$ & $\begin{array}{l}143.9 \\
148.5 \\
153.7 \\
158.4 \\
162.1\end{array}$ & $\begin{array}{l}-46.9 \\
-55.5 \\
-56.9 \\
-56.1 \\
-54.8\end{array}$ \\
\hline
\end{tabular}


TABLE 1 - Continued

\begin{tabular}{|c|c|c|c|c|}
\hline $\begin{array}{c}\text { Sample } \\
\text { (Interval in } \mathrm{cm} \text { ) }\end{array}$ & $\begin{array}{l}\text { Demagnet- } \\
\text { izing Field } \\
\text { (oe) }\end{array}$ & $\begin{array}{c}\text { Magnitude }{ }^{\mathrm{c}} \\
\left(\times 10^{-7} \mathrm{emu} / \mathrm{cc}\right) \\
\text { Residue }(\%)\end{array}$ & $\begin{array}{l}\text { Declination } \\
\text { Mean }\left({ }^{\circ}\right)\end{array}$ & $\begin{array}{l}\text { Inclination } \\
\text { Mean }\left({ }^{\circ}\right)\end{array}$ \\
\hline $22-1,4-6$ & $\begin{array}{c}\text { NRM } \\
25 \\
50 \\
75^{\mathrm{a}} \\
100\end{array}$ & $\begin{array}{c}(3.92) \\
96 \\
85 \\
65 \\
63\end{array}$ & $\begin{array}{l}136.8 \\
149.7 \\
144.8 \\
147.0 \\
147.3\end{array}$ & $\begin{array}{l}-49.1 \\
-58.9 \\
-58.7 \\
-57.7 \\
-59.2\end{array}$ \\
\hline $22-1,6-8$ & $\begin{array}{c}\text { NRM } \\
25 \\
50 \\
75 \\
100\end{array}$ & $\begin{array}{c}(4.55) \\
96 \\
79 \\
70 \\
62\end{array}$ & $\begin{array}{l}145.8 \\
148.7 \\
149.6 \\
146.4 \\
149.2\end{array}$ & $\begin{array}{l}-51.9 \\
-61.4 \\
-60.6 \\
-64.1 \\
-62.0\end{array}$ \\
\hline $22-1,8-10$ & $\begin{array}{c}\text { NRM } \\
25 \\
50 \\
75 \\
100^{\mathrm{a}}\end{array}$ & $\begin{array}{c}(3.80) \\
91 \\
75 \\
68 \\
65\end{array}$ & $\begin{array}{l}146.2 \\
145.3 \\
146.8 \\
150.4 \\
146.8\end{array}$ & $\begin{array}{l}-51.6 \\
-57.8 \\
-59.9 \\
-59.7 \\
-59.7\end{array}$ \\
\hline $22-3,0-2$ & $\begin{array}{c}\mathrm{NRM}^{\mathrm{a}} \\
50 \mathrm{a}\end{array}$ & $\begin{array}{c}(2.15) \\
77\end{array}$ & $\begin{array}{l}270.9 \\
238.3\end{array}$ & $\begin{array}{l}-40.1 \\
-39.5\end{array}$ \\
\hline $22-3,2-4$ & $\begin{array}{c}\text { NRM } \\
50^{\mathrm{a}}\end{array}$ & $\begin{array}{c}(4.67) \\
83\end{array}$ & $\begin{array}{l}225.2 \\
235.5\end{array}$ & $\begin{array}{l}-59.5 \\
-63.8\end{array}$ \\
\hline $22-3,4-6$ & $\begin{array}{c}\text { NRM } \\
50\end{array}$ & $\begin{array}{c}(4.19) \\
88\end{array}$ & $\begin{array}{l}221.0 \\
219.9\end{array}$ & $\begin{array}{l}-51.3 \\
-58.3\end{array}$ \\
\hline $23-1,144-146$ & $\begin{array}{c}\text { NRM } \\
50^{\mathrm{a}}\end{array}$ & $\begin{array}{c}(4.33) \\
74\end{array}$ & $\begin{array}{l}145.7 \\
132.9\end{array}$ & $\begin{array}{l}-32.0 \\
-48.6\end{array}$ \\
\hline $23-1,146-148$ & $\begin{array}{c}\mathrm{NRM} \\
50^{\mathrm{a}}\end{array}$ & $\begin{array}{c}(3.49) \\
82\end{array}$ & $\begin{array}{l}138.3 \\
134.6\end{array}$ & $\begin{array}{l}-49.1 \\
-62.2\end{array}$ \\
\hline $23-1,148-150$ & $\begin{array}{c}\text { NRM } \\
50^{\mathrm{a}}\end{array}$ & $\begin{array}{c}(3.79) \\
77\end{array}$ & $\begin{array}{l}152.1 \\
161.0\end{array}$ & $\begin{array}{l}-55.5 \\
-61.8\end{array}$ \\
\hline $23-2,103-105$ & $\begin{array}{c}\text { NRM } \\
50\end{array}$ & $\begin{array}{c}(3.58) \\
86\end{array}$ & $\begin{array}{l}224.0 \\
243.0\end{array}$ & $\begin{array}{l}55.7 \\
67.7\end{array}$ \\
\hline $23-2,105-107$ & $\begin{array}{c}\text { NRM } \\
50\end{array}$ & $\begin{array}{c}(3.44) \\
86\end{array}$ & $\begin{array}{l}225.7 \\
239.5\end{array}$ & $\begin{array}{l}48.0 \\
59.9\end{array}$ \\
\hline $23-2,107-109$ & $\begin{array}{c}\mathrm{NRM}^{\mathrm{a}} \\
50^{\mathrm{a}}\end{array}$ & $\begin{array}{c}(2.93) \\
100\end{array}$ & $\begin{array}{l}242.1 \\
245.0\end{array}$ & $\begin{array}{l}56.6 \\
64.1\end{array}$ \\
\hline $23-2,109-111$ & $\begin{array}{r}\text { NRM } \\
50^{\mathrm{b}}\end{array}$ & $(2.86)$ & 279.9 & 53.2 \\
\hline $23-2,111-113$ & $\begin{array}{c}\mathrm{NRM}^{\mathrm{a}} \\
50^{\mathrm{a}}\end{array}$ & $\begin{array}{c}(2.48) \\
61\end{array}$ & $\begin{array}{l}255.8 \\
309.2\end{array}$ & $\begin{array}{l}42.9 \\
46.0\end{array}$ \\
\hline $23-3,102-104$ & $\begin{array}{c}\text { NRM } \\
50\end{array}$ & $\begin{array}{c}(6.50) \\
68\end{array}$ & $\begin{array}{l}136.2 \\
132.0\end{array}$ & $\begin{array}{l}-66.0 \\
-63.3\end{array}$ \\
\hline $23-3,104-106$ & $\begin{array}{c}\text { NRM } \\
50\end{array}$ & $\begin{array}{c}(6.42) \\
75\end{array}$ & $\begin{array}{l}125.6 \\
116.8\end{array}$ & $\begin{array}{l}-75.3 \\
-67.6\end{array}$ \\
\hline $23-3,106-108$ & $\begin{array}{c}\text { NRM } \\
50^{\mathrm{a}}\end{array}$ & $\begin{array}{c}(5.20) \\
70\end{array}$ & $\begin{array}{l}160.0 \\
126.7\end{array}$ & $\begin{array}{l}-38.5 \\
-55.3\end{array}$ \\
\hline $23-4,84-86$ & $\begin{array}{c}\text { NRM } \\
50\end{array}$ & $\begin{array}{c}(3.56) \\
88\end{array}$ & $\begin{array}{l}175.2 \\
184.6\end{array}$ & $\begin{array}{l}-50.9 \\
-56.9\end{array}$ \\
\hline $23-4,86-88$ & $\begin{array}{c}\text { NRM } \\
50\end{array}$ & $\begin{array}{c}(5.90) \\
64\end{array}$ & $\begin{array}{l}175.8 \\
186.8\end{array}$ & $\begin{array}{l}-72.6 \\
-69.1\end{array}$ \\
\hline $23-4,88-90$ & $\begin{array}{c}\text { NRM } \\
50\end{array}$ & $\begin{array}{c}(5.43) \\
64\end{array}$ & $\begin{array}{l}180.9 \\
174.0\end{array}$ & $\begin{array}{l}-59.8 \\
-61.6\end{array}$ \\
\hline $23-5,61-63$ & $\begin{array}{c}\text { NRM } \\
50\end{array}$ & $\begin{array}{c}(5.88) \\
52\end{array}$ & $\begin{array}{l}151.5 \\
129.3\end{array}$ & $\begin{array}{l}-59.1 \\
-63.1\end{array}$ \\
\hline $23-5,63-65$ & $\begin{array}{c}\text { NRM } \\
50\end{array}$ & $\begin{array}{c}(4.71) \\
70\end{array}$ & $\begin{array}{l}136.8 \\
124.6\end{array}$ & $\begin{array}{l}-55.2 \\
-60.7\end{array}$ \\
\hline $23-5,65-67$ & $\begin{array}{c}\text { NRM } \\
50\end{array}$ & $\begin{array}{c}(4.84) \\
72\end{array}$ & $\begin{array}{l}141.0 \\
131.7\end{array}$ & $\begin{array}{l}-51.7 \\
-53.6\end{array}$ \\
\hline $23-5,67-69$ & $\begin{array}{c}\text { NRM } \\
50\end{array}$ & $\begin{array}{c}(5.37) \\
72\end{array}$ & $\begin{array}{l}123.3 \\
115.9\end{array}$ & $\begin{array}{l}-66.7 \\
-66.7\end{array}$ \\
\hline $23-5,69-71$ & $\begin{array}{c}\text { NRM } \\
50\end{array}$ & $\begin{array}{c}(5.89) \\
69\end{array}$ & $\begin{array}{l}136.8 \\
136.7\end{array}$ & $\begin{array}{l}-64.2 \\
-63.3\end{array}$ \\
\hline
\end{tabular}


TABLE 1 - Continued

\begin{tabular}{|c|c|c|c|c|}
\hline $\begin{array}{c}\text { Sample } \\
\text { (Interval in } \mathrm{cm} \text { ) }\end{array}$ & $\begin{array}{l}\text { Demagnet- } \\
\text { izing Field } \\
\text { (oe) }\end{array}$ & $\begin{array}{c}\text { Magnitude }^{c} \\
\left(\times 10^{-7} \text { emu/cc) }\right. \\
\text { Residue }(\%)\end{array}$ & $\begin{array}{l}\text { Declination } \\
\text { Mean }\left({ }^{\circ}\right)\end{array}$ & $\begin{array}{c}\text { Inclination } \\
\text { Mean }\left({ }^{\circ}\right)\end{array}$ \\
\hline $23-5,140-142$ & $\begin{array}{l}\text { NRM } \\
50\end{array}$ & $\begin{array}{c}(4.86) \\
79\end{array}$ & $\begin{array}{l}357.1 \\
344.6\end{array}$ & $\begin{array}{l}-76.5 \\
-66.5\end{array}$ \\
\hline $23-5,142-144$ & $\begin{array}{l}\mathrm{NRM}^{\mathrm{a}} \\
50\end{array}$ & $\begin{array}{c}(4.11) \\
78\end{array}$ & $\begin{array}{l}341.1 \\
337.0\end{array}$ & $\begin{array}{l}-81.0 \\
-68.6\end{array}$ \\
\hline $23-5,144-146$ & $\begin{array}{c}\text { NRM } \\
50\end{array}$ & $\begin{array}{c}(4.27) \\
84\end{array}$ & $\begin{array}{l}9.1 \\
3.0\end{array}$ & $\begin{array}{l}-68.2 \\
-66.6\end{array}$ \\
\hline \multicolumn{5}{|c|}{$\begin{array}{l}{ }^{a} \text { Samples have a large nondipole component }(\mathrm{LNC}) \text { and are not considered } \\
\text { reliable. } \\
\mathrm{b}_{\text {Sample } 23-2,109-111 \text { was not measured after } 50 \text {-oe cleaning because of }} \\
\text { instrumental difficulties. } \\
\mathrm{c}_{\text {Magnitude }}\left(\mathrm{X}_{10^{-7}} \mathrm{emu} / \mathrm{cc}\right) \text { given in parentheses. }\end{array}$} \\
\hline
\end{tabular}

and illustrates how much the clustering improves after partial (50-oe) AF demagnetization. Figure 4 is a set of $5^{\circ}$ histograms, combining both normal and reversed samples, again showing the much improved clustering after AF cleaning, as well as the effect of removing the unreliable LNC samples.

The arithmetic mean inclination, its standard deviation, $\alpha^{*} 95, k^{*}$, and the number of samples are listed in Table 2 for various groups of samples.' The standard deviation may be a more realistic measure than the $\alpha^{*}{ }_{95}$ for the true error in the mean inclination. Thus, in determining the site paleolatitude, the mean inclination and the standard deviation for the 32 samples considered reliable after 50-oe AF cleaning were calculated as paleocolatitudes ${ }^{2}$ and plotted as small circles around the site's present location to give a locus within which the paleopole must lie. Figure 5 shows this plot, together with a portion of the polar wandering curve for Australia, taken from McElhinny (1973, p. 306).

\section{DISCUSSION}

The inclinations of normal and reversed samples are clearly consistent with each other, as seen in the histograms of Figures 3 and 4 . The pronounced

\footnotetext{
$1_{\alpha 95}$ is the semi-angle of the $95 \%$ confidence cone about the mean paleocoordinates. The indeterminacy of the sample declinations prevents meaningful estimates of $\alpha 95$. The declinations were arbitrarily set to $0^{\circ}$ for the calculation of the tabulated $\alpha^{*} 95$ which should be considered a minimum value of $\alpha 95$. The same assumption was made in calculating $k^{*}$. the accuracy parameter, using the usual formulas:

$$
\begin{aligned}
\alpha_{95}^{*} & =\cos ^{-1}\left[1-\frac{N-R}{R}\left\{\left(\frac{1}{0.05}\right)^{1 / N-1}-1\right\}\right] \\
k^{*} & =\frac{N-1}{N-R}
\end{aligned}
$$

where $N=$ number of samples, and $R^{2}=\left(\Sigma l_{i}\right)^{2}+\left(\Sigma m_{1}\right)^{2}+\left(\Sigma n_{1}\right)^{2}, l_{1}$, $m_{i}, n_{i}$ being direction cosines for moment vectors.

${ }^{2}$ The paleocolatidue, $p$, or alternatively, the paleolatitude, $L$, are defined from their relationship to the inclination of the remanent moment, $I$, by: $\tan I=2 \cot p=2 \tan L$.
}

clustering of the NRM inclinations about the mean in Figure $4 \mathrm{a}$ is an indication that the sediments have been relatively undisturbed since they acquired their remanence. The displacement of the mean inclination value, by about $4^{\circ}$, following partial AF demagnetization, suggests that a uniform secondary component of magnetic moment was thereby removed. As noted above, the declinations cannot be compared for samples which are not contiguous. No correlation was found between NRM intensity and the normal/reversed state. The sample mineralogy has not yet been investigated, so that chemically induced self-reversals cannot be excluded. Since the stability behavior of NRM in both normal and reversed samples is similar, there is no reason to presume that reversed remanence is secondary and that inclinations would revert to normal upon demagnetization in higher fields. Confirmation of these reversal events must await further extensive, continuous sampling of the cores (joint report with R. D. Jarrard, in preparation). At least one reversal in our data (Samples 20-3, 28-30 cm, Table 1) has been confirmed by R. D. Jarrard at Scripps (this volume, his Sample 20-3, 30-32 cm).

Figure 5 shows that there is close agreement between the calculated paleocolatitude and the previous data for Australia for the Cretaceous. The two sites used for the Cretaceous pole, $\mathrm{K}$ in Figure 5, were dated radiometrically at 104 m.y. and 93 m.y. (McElhinny, 1973, p. 306). However, this agreement cannot constrain the ages of the sampled sediments, since the mean paleocolatitude circle is nearly tangential to the polar wandering curve.

The inclination changes apparent between several contiguous samples at various intervals (Figure 1) could be attributed to secular variation effects and thus would be compatible with the sedimentation rates initially proposed of about $8 \mathrm{~cm} / 1000 \mathrm{yr}$. However, over the largest sampled interval of about $10 \mathrm{~cm}$, the sample inclinations seem to average out quite well. Since the secular variation is presently smoothed out in roughly 2000 years, a maximum sedimentation rate of about 5 $\mathrm{cm} / 1000 \mathrm{yr}$ is implied. Further contiguous sampling of longer intervals would provide more conclusive evidence of this effect. 
PALEOMAGNETIC RESULTS FOR SEDIMENTS

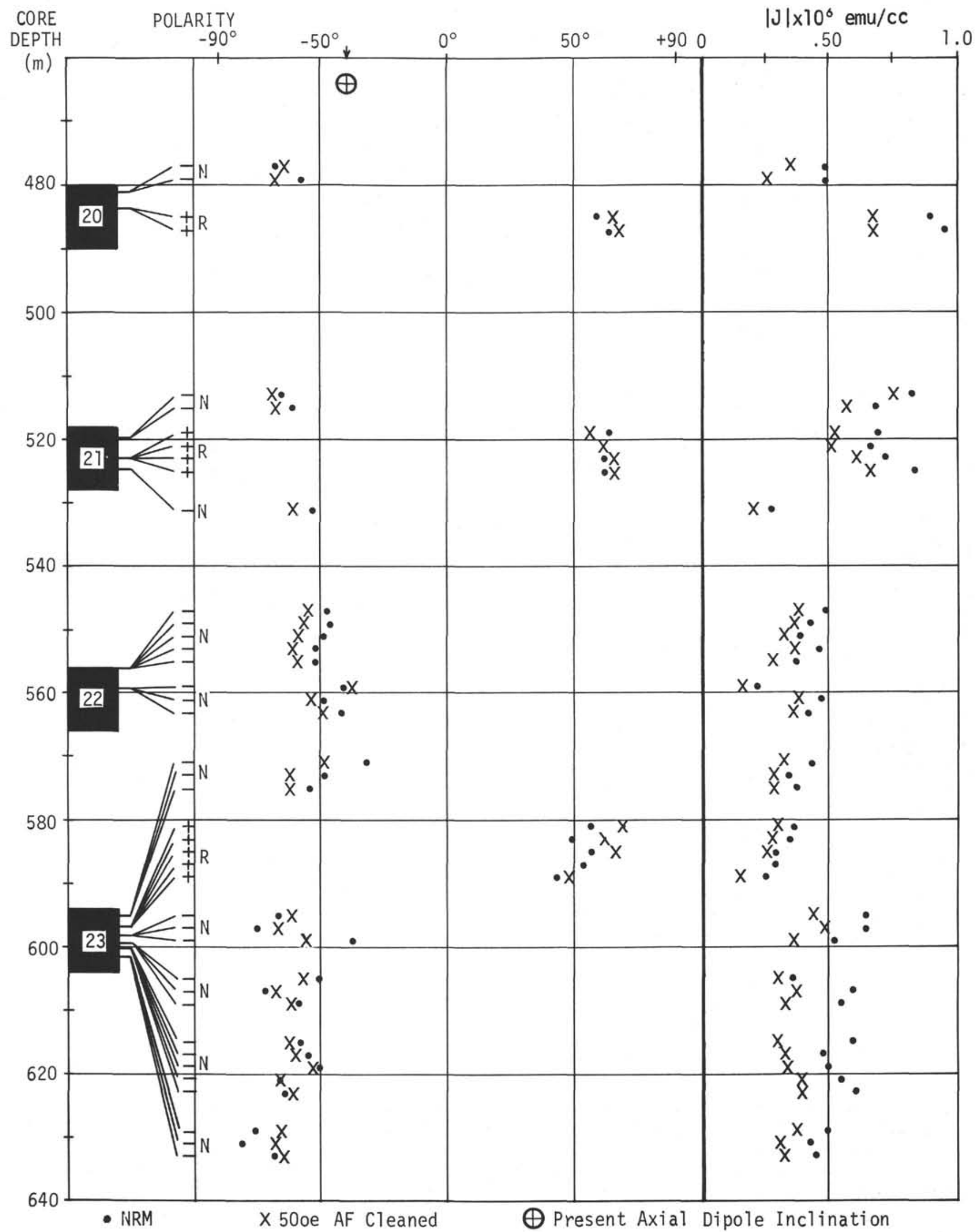

Figure 1. Inclination and magnetization intensity (NRM and after 50-oe cleaning) of 41 samples. Sample interval is given on the left. Shading indicates the core recovered. Depth is in meters below the ocean floor. 


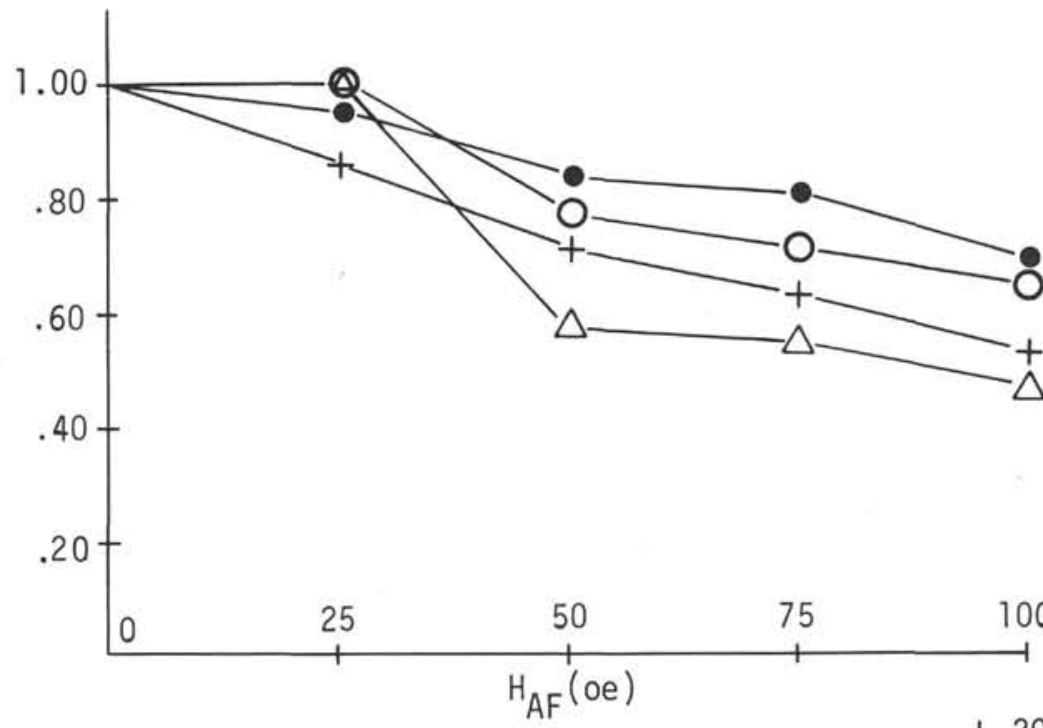

a $\quad+20-1,100-102$

$\triangle 20-1,102-104$

- 21-2, 4-6

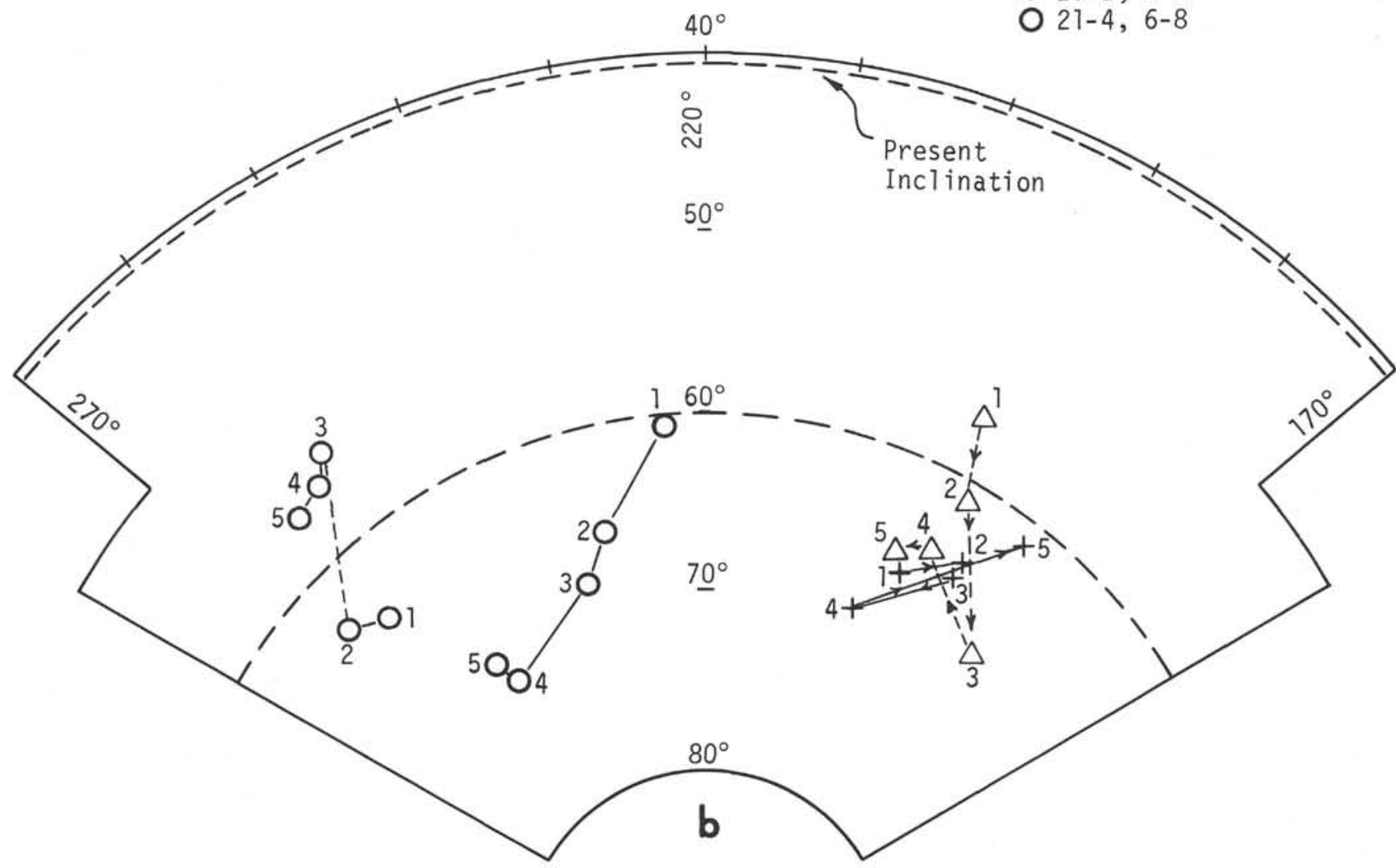

Figure 2. (a) Normalized intensities of remanence of four representative samples at each stage of partial demagnetization. Samples 20-1, 100-102 cm, 20-1, 102-104 cm, 21-2, 4-6 cm are of normal polarity. Sample 21-4, 6-8 cm has reverse polarity. (b) Directions of remanence for samples for each stage of partial AF demagnetization. The corresponding $A F$ peak fields are: 1-NRM; 2-25 oe; 3-50 oe; 4-75 oe; 5-100 oe. Note decreased rate of change in inclination with AF cleaning above 50 oe. Present axial geocentric dipole inclination is marked at $40.8^{\circ}$. 


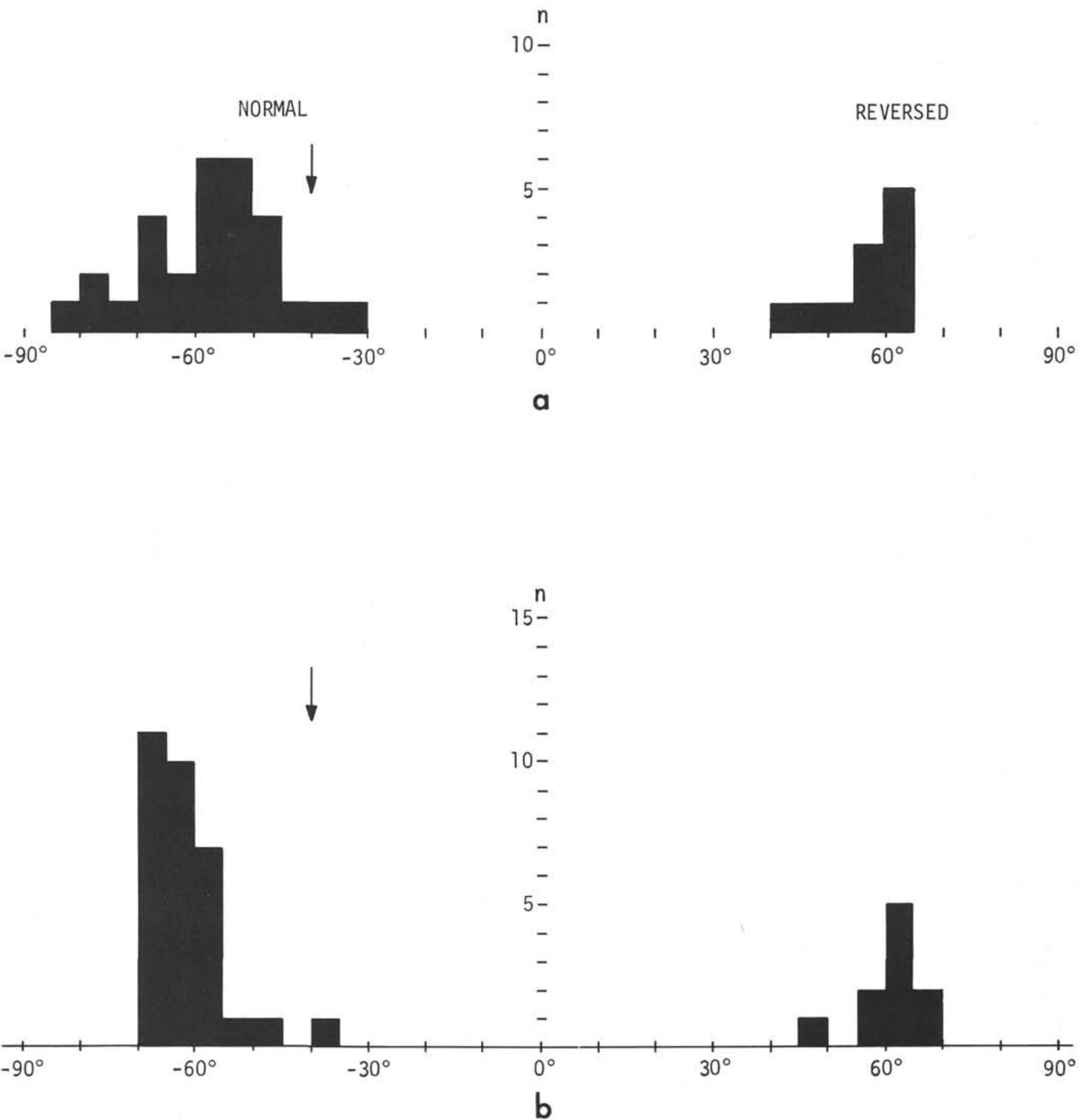

Figure $3.5^{\circ}$ histograms of sample inclinations versus number of samples: (a) NRM inclinations of normal and reverse polarity samples. (b) Inclinations following 50-oe cleaning showing improved clustering. Arrow marks the inclination of the present axial geocentric dipole field at Site 263. 

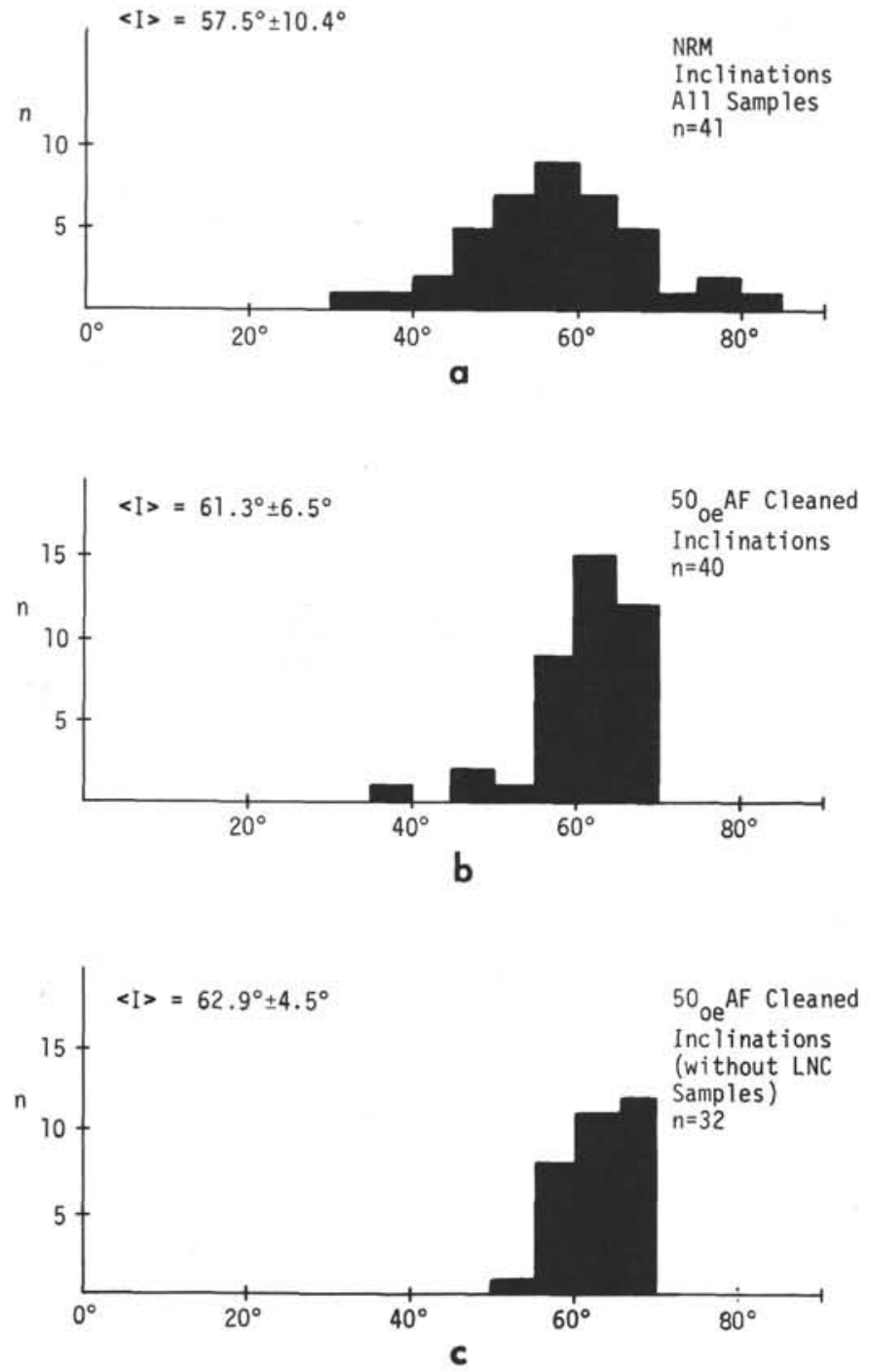

Figure $4.5^{\circ}$ histograms of the absolute value of the inclination versus number of samples. (a) NRM inclinations for 41 samples; arithmetic mean is $57.5^{\circ}$; standard deviation is $\pm 10.4^{\circ}$. (b) Inclinations of 40 samples following 50-oe AF cleaning; arithmetic mean is $61.3^{\circ}$; standard deviation is $\pm 6.5^{\circ}$. (c) Inclinations of 32 samples considered to have a reliable remanent moment following 50-oe cleaning; arithmetic mean is $62.9^{\circ}$; standard deviation is $\pm 4.5^{\circ}$.

The paleontological data used in dating this hole are still inconclusive (see Paleontology Section, this volume). Of 13 different intervals randomly sampled over a 204-meter interval, 3 are reversed in our data, indicating that a significant portion of the unsampled sediment between or within cores could be of reversed polarity. Because it is generally agreed that these cores are from the Lower Cretaceous, we would surmise that the cores predate the long normal polarity interval generally recognized for the Cretaceous (Irving and Couillard, 1973). Our sampling is too infrequent to establish a reversal stratigraphy or to allow unambiguous matching of these reversals to other cores or to a paleomagnetic time scale. We can say that it is unlikely that the samples are truly Albian, as implied by some

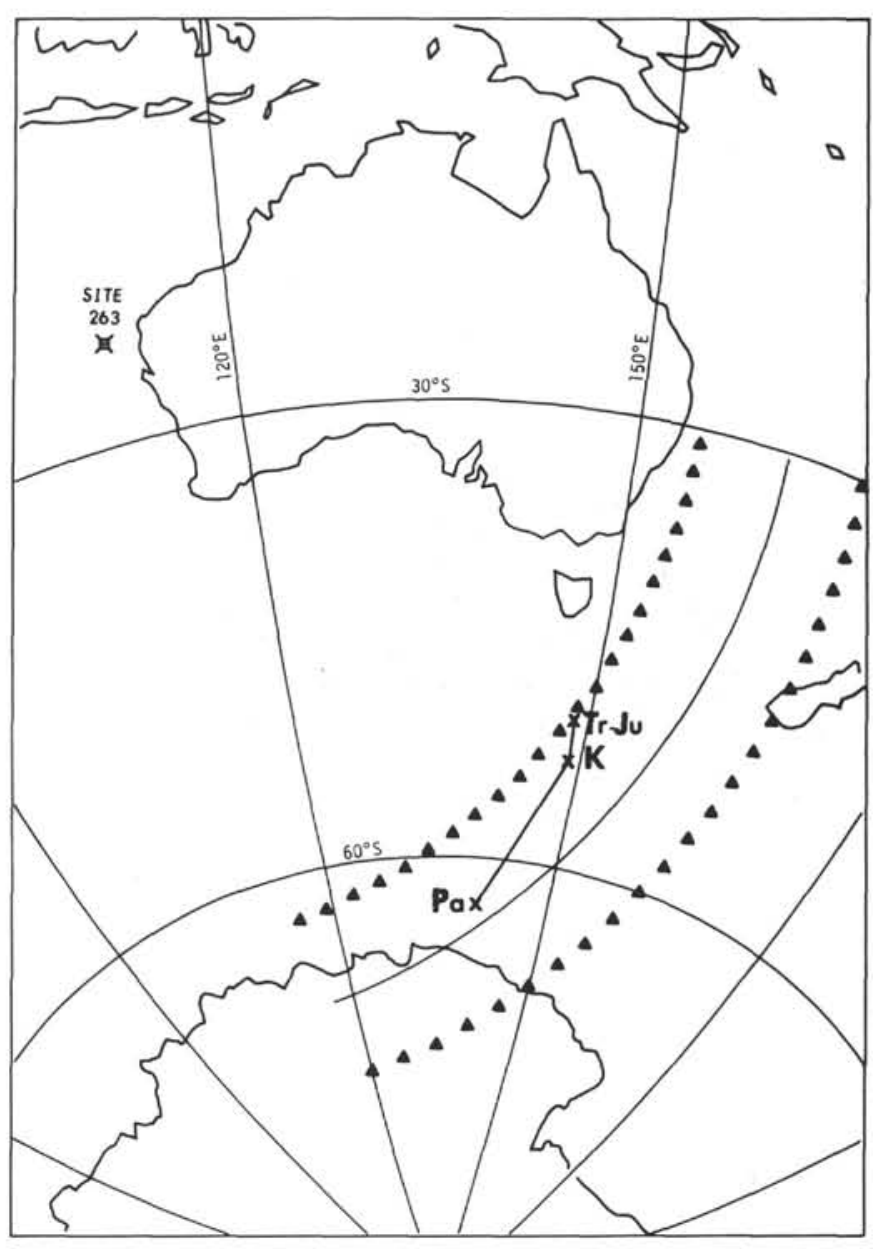

Figure 5. Lambert equal area projection, centered on $40^{\circ} \mathrm{S}$, $135^{\circ} \mathrm{E}$, showing Site 263 , at $23^{\circ} 20^{\prime} \mathrm{S}, 110^{\circ} 58^{\prime} \mathrm{E}$, with the outlines of Australia, New Zealand, and Antarctica for reference. The solid line denotes the mean paleocolatitude for the 32 samples considered reliable following 50 -oe $A F$ cleaning with the triangles indicating the standard deviation. The polar wandering curve for Australia was constructed using the tabulated data (from McElhinney, p.306) for the Cretaceous (Pole K, Au 10. 1-2); the Triassic-Jurassic (Pole Tr-Ju, Au 8.1, 9. 1-5); and the Paleocene (Pole P, Au 11.1).

paleontological evidence, unless they represent very short reversal events which have thus far not been found on land (Irving and Couillard, 1973). If we assume a sedimentation rate of $5 \mathrm{~cm} / 1000 \mathrm{yr}$, the duration of observed reversed periods is a minimum of $1600 \mathrm{yr}$, and a maximum of $120,000 \mathrm{yr}$, based on our fragmentary data. These intervals could be stretched or shortened by assuming different sedimentation rates and are only meant as a guide. The presence and duration of these events can only be verified by further sampling.

Work now in progress will complete the study of the stability of NRM under further AF cleaning, as well as test the possibility of stable viscous remanence. The nature of the NRM, whether chemically or depositionally produced, and the magnetic mineralogy are also being investigated. 
TABLE 2

Inclination by Groups

\begin{tabular}{|c|c|c|c|c|c|c|}
\hline Group & $N$ & $\begin{array}{l}\text { Demagnet- } \\
\text { izing Field } \\
\text { (oe) }\end{array}$ & $\begin{array}{l}\text { Inclination } \\
\text { Mean }\left({ }^{\circ}\right)\end{array}$ & $\begin{array}{c}\alpha * 95 \\
\left({ }^{\circ}\right)\end{array}$ & $k^{*}$ & $\begin{array}{c}\text { Standard } \\
\text { Deviation }\left({ }^{\circ}\right)\end{array}$ \\
\hline All samples & 41 & NRM & 57.5 & 2.9 & 61 & 10.4 \\
\hline All samples less LNC values & 36 & NRM & 57.5 & 2.8 & 73 & 9.5 \\
\hline All samples & 40 & 50 & 61.3 & 1.8 & 158 & 6.5 \\
\hline All samples less LNC values & 32 & 50 & 62.9 & 1.4 & 326 & 4.5 \\
\hline All normal & 30 & 50 & 61.3 & 2.1 & 153 & 6.6 \\
\hline All reversed & 10 & 50 & 61.5 & 3.9 & 157 & 6.5 \\
\hline Core 20 & 4 & 50 & 65.9 & 1.6 & 3369 & 1.4 \\
\hline Core 21 & 7 & 50 & 63.4 & 3.5 & 291 & 4.8 \\
\hline Core 22 & 8 & 50 & 56.6 & 5.0 & 121 & 2.0 \\
\hline Core 23 & 21 & 50 & 61.6 & 2.5 & 162 & 4.5 \\
\hline
\end{tabular}

Note: In the computation of the tabulated values, all declinations were set to $0^{\circ}$, arbitrarily, and reversed inclinations were simply reversed in sign. One sample was not measured after cleaning due to instrumental difficulties.

\section{SUMMARY}

The paleomagnetic study of 41 samples from 13 intervals in four cores from Site 263 has yielded a reliable paleolatitude estimate $\left(44.3^{\circ} \pm 5.5^{\circ}\right)$ which is consistent with the paleolatitude of $48.4^{\circ}$ computed from the pole for the Australian plate during the Cretaceous.

The significant clustering of normal and reversed inclinations about the mean (Figures 3 and 4) strongly suggests that the three reversed polarity events uncovered are real. The presence of at least three periods of reversed polarity may indicate that the sampled sediment predates the Cretaceous normal polarity interval.

\section{ACKNOWLEDGMENTS}

We thank John Sclater for initiating this project and for his support. The work benefited greatly from the advice and help of John Peirce and Charles Denham from Woods Hole Oceanographic Institution. Richard D. Jarrard is thanked for sampling the cores. Financial support for K. E. Green was provided in part by the MIT Undergraduate Research Opportunities Program.

\section{REFERENCES}

Doell, R. R. and Cox, A., 1965. Measurement of the remanent magnetization of igneous rocks: U.S. Geol. Surv. Bull. 1203-A, p.1.

Irving, E. and Couillard, R. W., 1973. Cretaceous normal polarity interval: Nature Phys. Sci., v. 244, p. 10.

McElhinny, M. W., 1973. Paleomagnetism and plate tectonics: Cambridge (Cambridge University Press). 